
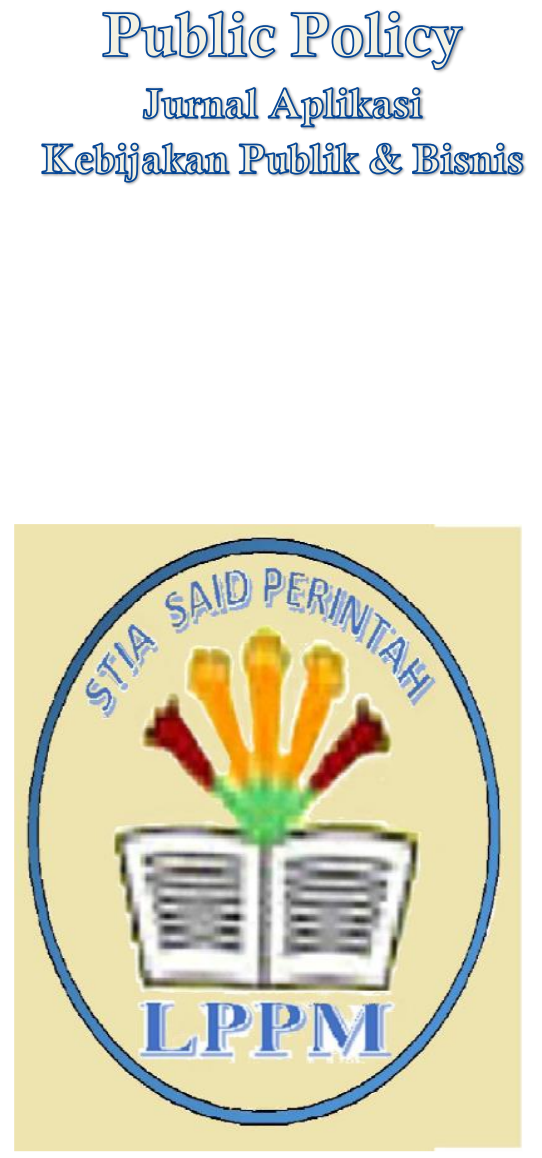

Volume 1, No. 1, Maret 2020

LPPM STIA Said Perintah

stia-saidperintah.e-journal.id

\section{Model Minat Kunjungan Wisata Berdasarkan Lingkungan Fisik, Sikap dan Norma Subyektif}

\author{
Mohammad Amin \\ Program Studi Niaga STIA Said Perintah \\ amoh75656@gmail.com
}

\begin{abstract}
The purpose of this study was to examine and analyze the influence of the physical environment, attitudes and subjective norms on the interest of visiting tourists in Ora Beach. The population of this study are all domestic and foreign tourists who while visiting Ora Beach tourism objects from the period of February to March 2019. Sampling using accidental sampling technique with a final sample of 49 respondents. Analysis of research data using Multiple Linear Regression Analysis.

The results showed that the physical environment, attitudes and subjective norms proved to have a positive and significant effect on the interest of visiting tourists in Ora Beach. This can be proven through the regression coefficient of the physical environment and attitude which shows that if the value of the physical environment, attitudes and subjective norms increase, the increase will be followed by an increase in tourist interest in visiting Ora Beach. Thus it can be said that increasing the value of the physical environment, attitudes and subjective norms will increase the interest of tourists visiting Ora Beach.
\end{abstract}

Keywords : Physical Environment, Attitudes, Subjective Norms, Interests

\section{Pendahuluan}

Sektor pariwisata di Indonesia akan terus meningkat dari waktu ke waktu dilihat dari berbagai indikator. Dari segi kedatangan internasional, dari tahun 1950 sampai 2015 peningkatan jumlah kunjungan wisatawan internasional bergerak dari 25 juta sampai 1.2 miliar turis (Kalebos, 2016) dengan pertumbuhan setiap tahunnya rata-rata sekitar 6\%. Jumlah kunjungan wisatawan mancanegara ke Indonesia pada tahun 2018 sebanyak 15.81 juta wisatawan. Bila dibandingkan tahun 2017, kunjungan wisatawan mancanegara naik 12.58 persen (Wahyu Adityo Prodjo, 2019). Hal ini membuat peringkat indeks daya saing 
pariwisata Indonesia di dunia naik menjadi peringkat 40 di tahun 2019 dari peringkat 42 ditahun 2017 dan dikawasan Asia Tenggara, indeks daya saing pariwisata Indonesia berada diperingkat empat (Wahyu Adityo Prodjo, 2019). Fakta ini menunjukan bahwa sektor pariwisata sebagai sektor yang berbasis jasa merupakan salah satu sektor potensial bagi pembangunan nasional karena mampu mendatangkan devisa dan untuk itu maka langkah- langkah strategis untuk mendorong pelaku industri pariwisata agar lebih berperan dalam memikat wisatawan mancanegara dan mendorong terjadinya transaksi bisnis di pasar wisata menjadi hal mutlak yang harus ditempuh pemerintah

Salah satu destinasi wisata di Indonesia adalah Provinsi Maluku khususnya di Kabupaten Maluku Tengah. Kabupaten Maluku Tengah sendiri memiliki kekayaan sumberdaya alam hayati yang berlimpah baik didarat maupun di laut. Semua potensi ini mempunyai peranan yang penting bagi pengembangan kepariwisataan, khususnya wisata alam. Kabupaten ini memiliki daerah tujuan wisata yang cukup dikenal baik wisatawan domestik maupun wisatawan mancanegara seperti; Taman Laut Banda, Pantai Ora, Pantai Natsepa, Pantai Liang, Taman Nasional Manusela Potensi wisata ini haruslah dikembangkan secara baik sehingga mampu memperoleh kunjungan wisatawan baik dari dalam negeri maupun mancanegara dalam tingat yang tinggi.

Hal ini sangat mungkin untuk diwujudkan karena adanya perubahan khususnya perilaku konsumen. Dewasa ini perkembangan teknologi dan perubahan gaya hidup cenderung berbanding terbalik konsep marketing stimuli untuk suatu keputusan pembelian. Hasil kajian empiris (Del I Hawkins; David L Mothersbaugh; Roger J Best, 2007) mengungkapkan pandangan berbeda mengenai peran struktur harga terhadap niat membeli konsumen dan bukan merupakan determinan yang mutlak dalam hal pertimbangan konsumen dalam aktivitas pembelian. Hasil kajian tersebut membuktikan bahwa faktor situasional merupakan lingkungan yang mempengaruhi keputusan konsumen.

Fenomena tersebut merupakan gambaran kecenderungan pergeseran pola keputusan pembelian konsumen, yang berdasarkan kebutuhan beralih pada pertimbangan lingkungan. Lingkungan dapat mempengaruhi tangggapan afeksi dan kognisi serta perilaku konsumen. Afeksi dan kognisi adalah bentuk tanggapan psikologis. Afeksi mengacu pada tanggapan perasaan, sementara kognisi terdiri dari tanggapan mental (pemikiran). Orang dapat mengalami empat jenis tanggapan afeksi; emosi, perasaan tertentu, suasana hati, dan evaluasi. Setiap jenis afeksi dapat 
melibatkan tanggapan positif atau negatif (Peter. J, Paul \& Olson. Jerry, 1999). Sehingga konsumen menggunakan pertimbangan afektif dan kognitif untuk mengambil keputusan pembelian (Salomon, Michael, 2002). Intens kecenderungan pergeseran pola keputusan pembelian konsumen tersebut secara aktual dapat dibuktikan dari lahirnya minat untuk mengkonsumsi barang atau jasa. Hal ini juga terjadi dalam industri pariwisata sebagai salah satu industri terbesar di dunia dalam era globalisasi seperti yang diutarakan oleh John Naisbitt, (1994) dalam Global Paradox.

Berdasarkan pemaparan diatas maka stimulan lingkungan ini bersumber dari banyak faktor, namun bila disederhanakan berdasarkan konteks pariwisata di Indonesia, maka stimulan lingkungan ini dapat bersumber dari; sikap, lingkungan fisik dan norma subyektif. Pernyataan ini dibuktikan oleh hasil kajian-kajian empiris menyangkut faktor-faktor diatas antara lain; hasil kajian empiris yang disampaikan oleh Anugerah Prabudi Trapsila, (2005) yang menyatakan bahwa sikap berpengaruh positif terhadap minat kunjungan wisata. Hasil yang sejalan juga disampaikan oleh Anggrein, (2009) yang membuktikan bahwa sikap dan norma subyektif berpengaruh signifikan terhadap minat konsumen obyek agrowisata Pagilaran. Sementara hasil kajian tentang pengaruh lingkungan fisik disampaikan oleh (Amalia \& Ekwarso,
Hendro, 2017) yang berhasil membuktikan bahwa lingkungan fisik berpengaruh signifikan terhadap kunjungan wisatawan di museum daerah sang nila utama Kota Pekanbaru.

Berdasarkan pemaparan realita, fenomena dan hasil kajian empiris diatas maka peneliti tertarik untuk menguji dan menganalisis dampak sikap, lingkungan fisik dan norma subyektif terhadap minat kunjungan wisata di Kabupaten Maluku Tengah. Diharapkan memalui hasil kajian ini dapat memberi masukan bagi pemerintah daerah dalam upaua untuk meningkatkan jumlaj kunjungan wisata di Kabupaten Maluku Tengah.

\section{Kajian Pustaka \\ Teori Tindakan Beralasan (Theory of Reasonned Action)}

Teori tindakan beralasan ini dikembangkan oleh Icek Ajzen dan Martin Fishbein. Teori ini diderivasi dari penelitianpenelitian sebelumnya yang dimulai dari teori sikap (theory of attitude) yang mempelajari tentang sikap (attitude) dan perilaku (behavior). Theory of Reasonned Action (TRA) oleh Ajzen, (1991) ini lahir karena kurang berhasilnya penelitianpenelitian yang menguji teori sikap, yaitu hubungan antara sikap dan perilaku. Hasilhasil dari penelitian yang menguji teori sikap ini kurang memuaskan karena ditemukan hasil hubungan yang lemah antar pengukuran-pengukuran sikap (attitude) 
dengan kinerja dari perilaku sukarela yang dikehandaki.

Lebih lanjut, Ajzen,

mengemukakan teori tindakan beralasan dengan mencoba melihat anteseden penyebab perilaku volitional (perilaku yang dilakukan atas kemauan sendiri), teori tindakan beralasan ini didasarkan pada asumsi-asumsi;

1. Bahwa manusia pada umumnya melakukan sesuatu dengan cara-cara yang masuk akal.

2. Bahwa manusia mempertimbangkan semua informasi yang ada dan,

3. Bahwa secara eksplisit maupun implisit manusia memperhitungkan implikasi tindakan mereka.

Poin penting tentang perilaku menurut kemauan sendiri (volitional behavior) atau perilaku-perilaku yang diinginkan (willfull behavior) adalah perilaku-perilaku yang kejadiannya merupakan suatu hasil langsung dari usaha-usaha dibawah sadar (deliberate attempts) yang dibuat seseorang individual.

\section{Gambar Model Teori Tindakan Beralasan}

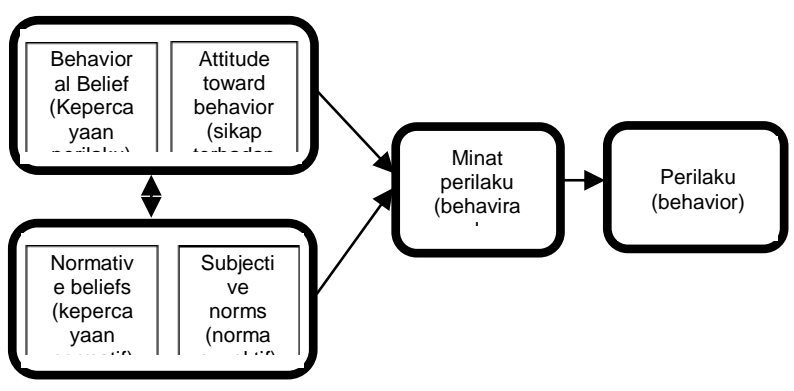

Sumber; Jogiyanto Hartono, ( 2007)

\section{Teori Perilaku Terencana (Theory of Planned Behavior)}

Teori Perilaku Terencana merupakan pengembangan lebih lanjut dari Theory of Reasoned Action (TRA) Ajzen, (1991) mengembangkan teori Theory of Planned Behavior (TPB) ini dengan menambahkan sebuah konstruk yang belum ada di TRA. Konstruk ini disebut dengan kontrol perilaku yang dipersepsi (perceived behavioral control). Konstruk ini ditambahkan di TPB untuk mengontrol perilaku individual yang dibatasi oleh kekurangan-kekurangannya dan keterbatasan-keterbatasan dari kekurangan sumber daya yang digunakan untuk melakukan perilakunya. Hal ini dapat dilihat pada gambar berikut;

\section{Gambar Model Teori Perilaku Terencana}

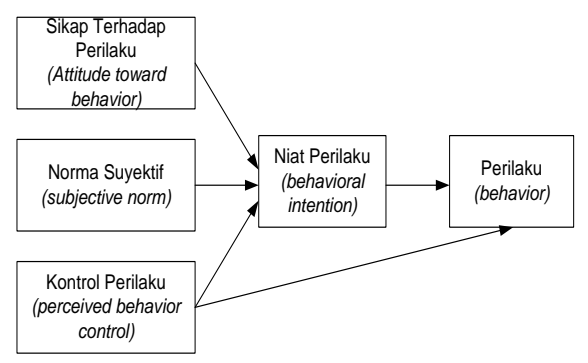

Sumber : Ajzen, 1991

Teori perilaku terencana (TPB) dapat mempunyai dua fitur sebagai berikut antara lain;

1. Teori ini mengasumsikan bahwa kontrol perilaku yang dipersepsi (perceived behavior control) mempunyai implikasi motivational terhadap minat. Orangorang percaya bahwa mereka tidak mempunyai sumber daya yang ada 
atau tidak mempunyai kesempatan untuk melakukan perilaku tertentu mungkin tidak akan membentuk minat perilaku (intentional behavior) yang kuat untuk melakukannya. Walaupun mereka mempunyai sikap (attitude) yang positif terhadap perilakunya dan percaya bahwa orang lain akan menyetujui seandainya mereka melakukan perilaku tersebut. Dengan demikian diharapkan dan terjadi hubungan antara kontrol perilaku yang dipersepsi (perceived behavioral control) dengan minat (intention) yang tidak dimediasi oleh sikap. Dimodel ini ditunjukkan dengan panah kontrol yang menghubungkan kontrol perilaku yang dipersepsi (perceived behavioral control) ke minat (intention).

2. Fitur kedua adalah kemungkinan hubungan langsung antara kontrol perilaku yang dipersepsi (perceived behavioral control) dengan perilaku. Di banyak contoh, kinerja dari suatu perilaku tergantung tidak hanya pada motivasi untuk melakukannya tapi juga kontrol yang cukup terhadap perilaku yang dilakukan. Dengan demikian kontrol perilaku yang dipersepsi dapat mempengaruhi perilaku secara tidak langsung lewat minat (intention), dan juga dapat memprediksi perilaku secara langsung. Di model hubungan langsung ini ditunjukkan dengan panah yang menghubungkan kontrol perilaku yang dipersepsi langsung ke perilaku (behavior).

Teori perilaku terencana secara eksplisit mengenai kemungkinan bahwa perilaku tidak semuanya dibawah kontrol penuh sehingga konsep dari kontrol perilaku yang dipersepsi ditambahkan untuk menangani perilaku semacam ini. Jika semua perilaku dapat dikontrol sepenuhnya oleh individu, yaitu kontrol perilaku yang mendekati maksimum, maka teori perilaku terencana kembali menjadi teori tindakan beralasan.

\section{Sikap Terhadap Perilaku}

Ajzen, (1991) menyatakan bahwa sikap adalah suatu bentuk evaluasi atau reaksi perasaan mendukung atau memihak (favorable) maupun perasaan mendukung atau tidak memihak (unfovarable) pada obyek tersebut. Sikap meliputi rasa suka dan tidak suka, mendekati dan menghindari situasi, benda, orang, kelompok dan aspek lingkungan yang dapat dikenal lainnya, termasuk gagasan abstrak dan kebijakan sosial.

Ajzen, (1991) membedakan dua macam sikap (attitude), yaitu terhadap obyek (attitude toward objek) dan sikap mengenai perilaku (attitude concerning behavior). Sikap terhadap obyek merupakan perasaan seseorang terhadap benda-benda atau obyek-obyek. Misalnya seseorang mengatakan system informasi yang baru ini 
diluar biasa atau sebaliknya mengatakan "system informasi yang baru sangat jelek". Contoh ini menunjukkan bahwa perasaan seseorang terhadap suatu obyek yaitu system informasi yang baru. Fishbein dan Ajzen berargumentasi dan menunjukkan bukti empiris bahwa suatu sikap terhadap obyek tidak kuat memprediksi perilaku spesifik terhadap obyek tersebut. Sebaliknya suatu sikap mengenai perilaku lebih dapat menentukan apakah suatu perilaku spesifik dilakukan atau tidak.

\section{Norma Subyektif}

Menurut Jogiyanto Hartono, ( 2007) norma subjektif adalah persepsi atau pandangan seseorang terhadap kepercayaan-kepercayaan orang lain yang akan memengaruhi seseorang tersebut untuk melakukan atau tidak melakukan perilaku yang sedang dipertimbangkan. Dharmmesta, (1998) mengemukakan norma subjektif diartikan sebagai faktor sosial yang menunjukkan tekanan sosial yang dipersepsikan untuk memutuskan atau tidak memutuskan walaupun keputusan sendiri menguntungkan jika pertimbangan orang lain tidak dianggap penting keputusan itu bisa gagal.

Didalam Theory of Planned Behavior, norma subjektif (subjective norms) dipengaruhi oleh kepercayaan-kepercayaan normatif (normative beliefs), yaitu kepercayaan tentang harapan yang dimiliki oleh individu yang melakukan perilaku terhadap pandangan orang lain agar dapat menerima dan melakukan motivasi terhadap perilaku yang ditunjukkan. Jadi, norma subjektif adalah persepsi seseorang tentang pengaruh sosial dalam membentuk perilaku tertentu. Seseorang bisa terpengaruh atau tidak terpengaruh oleh tekanan sosial.

\section{Lingkungan Fisik}

Shamdasani, P.N. \& Balakrishnan, (2000) menyatakan dimensi lingkungan fisik adalah semua faktor fisik yang dapat dikendalikan perusahaan untuk memicu meningkatkan (atau memaksa) tindakan karyawan dan pelanggan. Faktor-faktor tersebut adalah Symbol dan artifacts, barang-barang seperti kualitas material yang digunakan, kecanggihan teknologi dalam perlengkapan, dan sertifikat prestasi merupakan symbol yang mengomunikasikan arti dan kesan keindahan seluruhnya (Bitner, 1992). Faktor penting lainnya yang merupakan dimensi dari physical environment adalah penataan ruangan dan kefungsian dari lingkungan fisik. Penataan ruangan merupakan cara mengatur mesinmesin, peralatan, dan furnitur terkait ukuran dan bentuk barang tersebut dan keterkaitan barang tersebut dengan barang lainnya di ruangan. Kefungsian merupakan kemampuan suatu barang untuk membantu kinerja dan mencapai tujuan. Papan petunjuk informasi (signage), simbol dan hiasan. Banyak barang dalam lingkungan fisik mengomunikasikan suatu tempat 
kepada pengunjung, baik secara eksplisit maupun implisit (Bitner, 1992).

\section{Minat Konsumen}

Minat konsumen adalah keputusan konsumen mengenai preferensi atas merekmerek yang ada didalam kumpulan pilihan (Kotler dan Keler, 2009). Definisi lain minat konsumen adalah semua tindakan konsumen untuk memperoleh dan menggunakan barang dan jasa (Mowen, 2002). Menurut Lamb, (2002) minat konsumen adalah proses seseorang pelanggan dalam membuat dan menggunakan barang dan jasa yang dibeli.

Konsumen dapat membentuk niat untuk membeli merek yang paling disukai. Namun, ada dua faktor yang dapat berada diantara niat pembelian dan keputusan pembelian, yaitu sikap dan faktor situasi yang tidak terantisipasi (Kotler Philip, 2005). Sejauh mana sikap orang lain mengurangi alternatif yang disukai seseorang akan bergantung pada dua hal, yaitu; intensitas sikap negatif orang lain terhadap alternatif yang disukai konsumen, (2) motivasi konsumen untuk menuruti keinginan orang lain.

Semakin gencar sikap negatif orang lain dan semakin dekat orang lain tersebut dengan konsumen, konsumen akan semakin mengubah niat pembeliannya. Keadaan sebaliknya juga berlaku preferensi pembeli terhadap merek tertentu akan meningkat jika orang yang disukai juga sangat menyukai merek yang sama. Pengaruh orang lain menjadi rumit jika beberapa orang yang dekat dengan pembeli memiliki pendapat yang saling berlawanan dan pembeli tersebut ingin menyenangkan mereka (Kotler Philip, 2005).

\section{Kajian Empiris dan Hipotesis Penelitian}

Determinan minat berdasarkan stimuli lingkungan fisik disampaikan oleh Amalia \& Ekwarso, Hendro, (2017) yang berhasil membuktikan bahwa lingkungan fisik berpengaruh signifikan terhadap kunjungan wisatawan di museum daerah sang nila utama kota Pekanbaru. Hasil ini didukung oleh pendapat Hermansyah \& Waluya, (2012). Berdasarkan hasil kajian-kajian diatas maka hipotesis penelitian yang diajukan untuk diuji selanjutnya adalah;

$\mathrm{H}_{1}$; Lingkungan fisik berpengaruh positif dan signifikan terhadap minat kunjungan wisata di Pantai Ora (Ora Beach) Kabupaten Maluku Tengah.

Hasil kajian empiris tentang Determinan minat jika dilihat dari faktor sikap dan norma subyektif, disampaikan oleh Anugerah Prabudi Trapsila, (2005) yang menyatakan bahwa sikap berpengaruh positif terhadap minat kunjungan wisata. Hasil yang sejalan juga disampaikan oleh (Anggrein, 2009) yang membuktikan bahwa sikap dan norma subyektif berpengaruh signifikan terhadap minat konsumen obyek agrowisata Pagilaran. Berdasarkan hasil kajian-kajian diatas maka hipotesis 
penelitian yang diajukan untuk diuji selanjutnya adalah;

$\mathrm{H}_{2}$; Sikap berpengaruh positif dan signifikan terhadap minat kunjungan wisata di Pantai Ora (Ora Beach) Kabupaten Maluku Tengah.

$\mathrm{H}_{3}$; Norma subyektif berpengaruh positif dan signifikan terhadap minat kunjungan wisata di Pantai Ora (Ora Beach) Kabupaten Maluku Tengah.

\section{Metode Penelitian}

Metode yang digunakan dalam penelitian ini adalah penelitian penjelasan. Jenis penelitian ini berusaha menjelaskan hubungan kasual antara beberapa variabel. Penelitian ini akan menguji pengaruh; lingkungan fisik sikap dan norma subyektif terhadap minat kunjungan wisata. Populasi dalam kajian ini adalah seluruh wisatawan baik domestik maupun mancanegara yang sementara berkunjung ke objek wisata Pantai Ora (Ora Beach) di Kabupaten Maluku Tengah periode antara bulan Februari sampai Maret 2019. Penetuan sampel yang akan digunakan dalam penelitian ini adalah menggunakan teknik accidental sampling (samping secara kebetulan) dengan sampel akhir sebesar 49 wisatawan.

Pengujian instrument dilakukan melalui pengujian validitas korelasi yang menggunakan rumus Product Moment Person dan reliabiltas dengan menggunakan nilai Cronbach Alpha. Teknik analisis data menggunakan analisis Regresi Linier Berganda yang didahului oleh pengujian asumsi klasik yang meliputi uji; Normalitas, Multikoleritas dan Heterokedastisitas. Sementara untuk pengujian hipotesis dilakukan melalui pengujian menggunakan uji t dengan tingkat signifikannya 5\%. Kriteria pengujiannya adalah; jika $t$ hitung $>t$ tabel maka HO ditolak dan Ha diterima (Imam Ghozali, 2005) yang artinya terdapat pengaruh; sikap, norma subyektif dan lingkungan fisik terhadap minat kunjungan wisata pada Pantai Ora (Ora Beach).

\section{Pembahasan Hasil Penelitian}

\section{Uji Instrumen Penelitian}

Pengujian validitas dan reliabilitas yang dilakukan dalam penelitian ini menggunakan SPSS versi 21.00. Hasil pengujian masing-masing variabel terlihat pada tabel dibawah ini.

Tabel Hasil Uji Validitas \& Realibilitas

\begin{tabular}{|c|c|c|c|c|}
\hline Item & $\begin{array}{c}\text { Korelasi } \\
\text { (r) }\end{array}$ & Ket & $\begin{array}{c}\text { Koef. } \\
\text { Cronbach } \\
\text { Alpha }\end{array}$ & Ket \\
\hline$X_{1.1}$ & 0.850 & Valid & \multirow{3}{*}{0.743} & \multirow{3}{*}{ Reliabel } \\
\hline$X_{1.2}$ & 0.841 & Valid & & \\
\hline$X_{1.3}$ & 0.744 & Valid & & \\
\hline & & & & \\
\hline $\mathrm{X}_{2.1}$ & 0.820 & Valid & \multirow{4}{*}{0.869} & \multirow{4}{*}{ Reliabe } \\
\hline$X_{2.2}$ & 0.887 & Valid & & \\
\hline$X_{2.3}$ & 0.850 & Valid & & \\
\hline$X_{2.4}$ & 0.830 & Valid & & \\
\hline & & & \multirow{4}{*}{0.920} & \multirow{4}{*}{ Reliabel } \\
\hline$X_{3.1}$ & 0.927 & Valid & & \\
\hline$X_{3.2}$ & 0.922 & Valid & & \\
\hline$X_{3.3}$ & 0.949 & Valid & & \\
\hline & & & & \\
\hline Y.1 & 0.777 & Valid & \multirow{5}{*}{0.888} & \multirow{5}{*}{ Realibe } \\
\hline$Y_{.2}$ & 0.815 & Valid & & \\
\hline$Y_{.3}$ & 0.834 & Valid & & \\
\hline$Y_{.4}$ & 0.842 & Valid & & \\
\hline Y.5 & 0.893 & Valid & & \\
\hline
\end{tabular}


Sumber; Hasil Pengolahan Data, (2019)

Hasil uji validitas dan realibilitas instrumen seluruh variabel pada tabel diatas memiliki hasil uji signifikan korelasi $(r)$ lebih besar dari 0.3 dan memiliki nilai koefisien cronbach's alpha diatas 0.6 sehingga variabel pada tiap item pertanyaan dikatakan valid dan reliabel untuk dapat digunakan dalam pengolahan data selanjutnya.

\section{Uji Asumsi Klasik}

Selanjutnya analisis data penelitian dillanjutkan dengan pengujian asumsi klasik. Hasil pengujian normalitas melalui normal probability plot seperti yang terlihat dibawah ini.

\section{Grafik Normal P-P Plot}

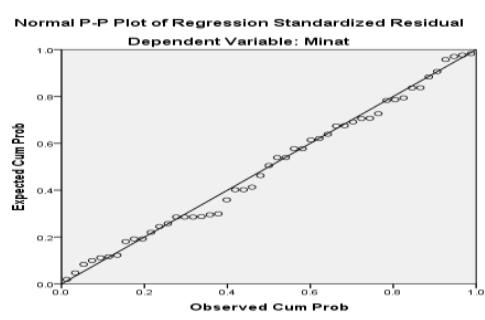

Grafik normal probability plot diatas menunjukkan bahwa titik-titik data menyebar disekitar garis diagonal serta penyebarannya mengikuti arah garis diagonal, dengan demikian sebaran data dapat dikatakan berdistribusi normal, sehingga bisa dilakukan regresi dengan model linear berganda.

Selanjutnya pengujian heteroskedastisitas dengan melihat penyebaran titik-titik pada grafik scatterplot seperti yang terlihat dibawah ini;

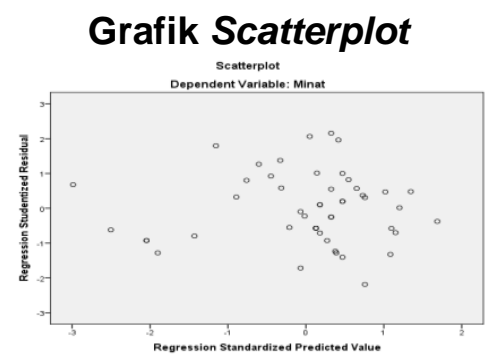

Grafik scatterplot diatas terlihat bahwa titik-titik menyebar secara acak serta tersebar baik diatas maupun dibawah angka 0 pada sumbu Y. Hal ini menunjukan kaidah heteroskedastisitas dalam model penelitian ini terpenuhi.

Pengujian asumsi klasik yang terakhir adalah uji multikolinieritas melalui nilai Variance Inflation Factor (VIF) dan nilai tolerance seperti yang terlihat dibawah ini.

Pengujian Multikolinieritas

\begin{tabular}{|l|c|c|}
\hline \multirow{2}{*}{\multicolumn{1}{|c|}{ Model }} & \multicolumn{2}{|c|}{ Collinearity Statistics } \\
\cline { 2 - 3 } & Tolerance & VIF \\
\hline Lingkungan fisik & 0.262 & 3.820 \\
\hline Sikap & 0.241 & 4.155 \\
\hline Norma Subyektif & 0.209 & 4.793 \\
\hline
\end{tabular}

Sumber; Hasil Pengolahan Data, (2019)

Data pada tabel diatas terlihat bahwa nilai Variance Inflation Factor (VIF) melebihi 0.10 dan nilai Tolerance dibawah 1 yang berarti tidak terjadi multikolinearitas antar variabel independen dalam penelitian ini.

\section{Analisis Regresi Linier Berganda}

Hasil pengolahan data dengan menggunakan alat statistik regresi linear berganda, dilakukan untuk menguji pengaruh antara lingkungan fisik $\left(\mathrm{X}_{1}\right)$, sikap $\left(X_{2}\right)$ dan norma subyektif $\left(X_{3}\right)$ terhadap minat 
berkunjung $(\mathrm{Y})$ wisatawandi Pantai Ora (Ora Beach). Hasil regresi dapat dilihat pada tabel dibawah ini;

\section{Hasil Analisis Regresi Linier Berganda}

\begin{tabular}{|c|c|c|c|c||}
\hline Variabel & $\begin{array}{c}\text { Unstand. } \\
\text { Coefficients } \\
\text { (B) }\end{array}$ & $\begin{array}{c}\mathbf{t} \\
\text { hitung }\end{array}$ & Sig. & Ket. \\
\hline \hline Constant & 1.755 & \multicolumn{3}{|l||}{} \\
\hline Lingkungan fisik & 0.597 & 3.378 & 0.002 & Sig. \\
\hline Sikap & 0.439 & 3.247 & 0.002 & Sig. \\
\hline Norma Subyektif & 0.398 & 2.020 & 0.049 & Sig. \\
\hline R Ajusted Square & 0.851 & & & \\
\hline t hitung & 1.677 & \multicolumn{3}{|l}{} \\
\hline
\end{tabular}

Sumber; Hasil Pengolahan Data, (2019)

\section{Pembahasan Hasil Penelitian}

Hasil pengujian hipótesis pertama mengungkapkan bahwa lingkungan fisik $\left(X_{1}\right)$ memiliki nilai $t$ hitung sebesar 3.378. Nilai ini lebih besar dari nilai $t$ tabel $(3.378>1.677)$ artinya bahwa, terima $\mathrm{Ha}$ dan tolak $\mathrm{HO}$ atau hipotesis pertama diterima. Hasil ini memperlihatkan bahwa lingkungan fisik berpengaruh positif dan signifikan terhadap minat wisatawan di Pantai Ora (Ora Beach).

Lingkungan fisik organisasi (service scape) merupakan salah satu strategi perusahaan jasa, dimana layanan diciptakan dan penyedia jasa dengan pelanggan berinteraksi, ditambah unsur-unsur berwujud yang ada dan dipakai untuk berkomunikasi atau untuk mendukung peran jasa (Bambang Widjajanta, 2015). Kemampuan lingkungan fisik organisasi untuk mempengaruhi perilaku konsumen dalam memutuskan membeli layanan jasa tertentu tergantung pada sikap responden terhadap lingkungan fisik organisasi (Bambang Widjajanta, 2015). Lingkungan fisik organisasi (service scape) yang diminati akan mendatangkan sikap positif terhadap jasa dan tanggapan positif terhadap jasa dan memutuskan untuk membeli jasa tersebut. Sedangkan lingkungan fisik organisasi (service scape) yang tidak diminati dapat menimbulkan sikap negatif dan akhirnya dapat menurunkan kesan jasa maupun perusahaan sehingga dapat menurunkan loyalitas responden dan kepuasan responden yang berdampak kepada penurunan loyalitas jasa (Bambang Widjajanta, 2015). Hasil temuan ini selaras dengan hasil yang disampaikan oleh; Amalia \& Ekwarso, Hendro, (2017); yang berhasil membuktikan bahwa lingkungan fisik berpengaruh signifikan terhadap kunjungan wisatawan di museum daerah sang nila utama kota Pekanbaru.

Hasil pengujian hipótesis kedua mengungkapkan bahwa sikap $\left(\mathrm{X}_{2}\right)$ memiliki nilai $t_{\text {hitung }}$ sebesar 3.247. Nilai ini lebih besar dari nilai $t$ tabel $(3.247>1.677)$ artinya bahwa, terima $\mathrm{Ha}$ dan tolak $\mathrm{HO}$ atau hipotesis kedua diterima. Hasil ini memperlihatkan bahwa sikap berpengaruh positif dan signifikan terhadap minat wisatawan di Pantai Ora (Ora Beach). Berdasarkan hasil análisis khususnya bila kita melihat análisis distribusi frekuensi jawaban responden, maka terlihat bahwa indikator tata letak dalam hal ini adalah keindahan alam pada tempat wisata 
Pantai Ora (Ora Beach) di Pantai Ora (Ora Beach) adalah yang relatif paling mempengaruhi minat kunjungan. Dasar pernyataan ini adalah karena besarnya nilai rata-rata indikator ini lebih besar dibandingkan indikator peran petugas atau karyawan ditempat wisata.

Dalam konsep pengambilan keputusan pembelian produk, maka keputusan konsumen tersebut sangat dipengaruhi oleh sikap dari konsumen terhadap produk tersebut. Sikap ini dapat dipengaruhi oleh pandangan konsumen yang bisa terbentuk dari pengalaman dan informasi yang didapatkan melalui berbagai sumber. Adanya pengalaman yang baik dan menyenangkan akan menumbuhkan sikap yang baik dari para konsumen sehingga akan terus melakukan pembelian produk yang sama (Anggrein, 2009).Temuan kajian ini mendukung hasil kajian terdahulu oleh; Anugerah Prabudi Trapsila, (2005) dan (Anggrein, 2009).

Hasil pengujian hipótesis terakhir atau yang ketiga mengungkapkan bahwa norma subyektif $\left(X_{3}\right)$ memiliki nilai $t$ hitung sebesar 2.020. Nilai ini lebih besar dari nilai $t$ tabel $(2.020>1.677)$ artinya bahwa, terima $\mathrm{Ha}$ dan tolak $\mathrm{HO}$ atau hipotesis ketiga juga diterima. Hasil ini memperlihatkan bahwa norma subyektif berpengaruh positif dan signifikan terhadap minat wisatawan di Pantai Ora (Ora Beach). Jika norma dikaitkan dengan proses pengambilan keputusan pembelian produk maka perilaku yang ditunjukkan oleh seseorang ketika melakukan pembelian suatu merek produk tertentu menjadi acuan orang-orang disekelilingnya untuk melakukan tindakan yang sama (Anggrein, 2009).

Hal ini karena adanya faktor kedekatan sehingga mereka bisa saling berkomunikasi (keluarga, teman, rekan dan bahkan melalui media cetak) memberikan informasi mengenai produk dan juga sebagai bentuk keseragaman untuk melakukan tindakan yang sama dengan orang-orang yang ada dikelompok sosialnya (Anggrein, 2009). Hasil temuan penelitian ini sejalan dengan hasil penelitian; Anugerah Prabudi Trapsila, (2005) dan (Anggrein, 2009).

\section{Kesimpulan}

Berdasarkan pembahasan hasil penelitian maka kesimpulan yang dapat disampaikan melalui kajian ini adalah; variabel lingkungan fisik, sikap dan norma subyektif terbukti berpengaruh secara positif dan signifikan terhadap minat kunjungan wisatawan di Pantai Ora (Ora Beach) atau dapat dikatakan bahwa peningkatan lingkungan fisik, sikap dan norma subyektif juga akan meningkatkan minat kunjungan wisatawan di Pantai Ora (Ora Beach).

\section{Daftar Pustaka}

Ajzen, I. (1991). The Theory of Planned Behavior. Organizational Behavior and 
Human Decision Processes, 50(2), 179-211. https://doi.org/10.1016/07495978(91)90020-T

Amalia, T., \& Ekwarso, Hendro, T. (2017). Pengaruh Lingkungan Fisik Terhadap Tingkat Kunjungan Wisatawan Di Museum Daerah Sang Nila Utama Kota Pekanbaru. Jurnal Online Mahasiswa Fakultas Ekonomi Universitas Riau, 4(1), 1201-1214.

Anggrein, I. D. (2009). Pengaruh Sikap dan Norma Subyektif Terhadap Minat Konsumen Obyek Agrowisata Pagilaran di Kabupaten Batang. Penelitian Mandiri.

Anugerah Prabudi Trapsila. (2005). Pengaruh Sikap Konsumen Pada Atribut Obyek Wisata Terhadap Minat Berkunjung (Studi Kasus Pada Obyek Wisata Alam Hutan Wisata Penggaron, Gua Kreo, Taman Lele dan Pantai Marina). Universitas Katolik

Soegijapranata Semarang.

Bambang Widjajanta, G. I. W. A. (2015).

Pengaruh Lingkungan Fisik Organisasi (Servicescape) Terhadap Keputusan Mengunjungi Museum Negeri Sri Baduga Bandung. Strategic Jurnal Pendidikan Manajemen Bisnis, 8(15). Bitner, M. J. (1992). Servicescapes: The Impact of Physical Surroundings on Customers and Employees. Journal of Marketing, $56(2)$, 57. https://doi.org/10.2307/1252042
Del I Hawkins; David L Mothersbaugh; Roger J Best. (2007). Consumer Behavior; Building Marketing Strategy. Retrieved from

https://www.worldcat.org/title/consumer -behavior-building-marketingstrategy/oclc/768314744\#borrow Dharmmesta, B. S. (1998). Theory of Planned Behavior dalam Penelitian Sikap, Minat, dan Perilaku Konsumen. Kelola, 7(18), 85-103.

Hermansyah, D., \& Waluya, B. (2012). Analisis Faktor-Faktor Pendorong Motivasi Wisatawan Nusantara Terhadap Keputusan Berkunjung ke Kebun Raya Bogor (Survei Pada Wisatawan Nusantara yang Berkunjung ke Kebun Raya Bogor). Tourism and Hospitality Essentials Journal, 11(1), 245-268.

Imam Ghozali. (2005). Aplikasi Analisis Multivariate Dengan Program SPSS, Edisi Ketiga (Edisi Ketiga). Semarang: Badan Penerbit Universitas Diponegoro.

Jogiyanto Hartono. (2007). Sistem Informasi Keperilakuan (1st ed.). Retrieved from http://openlib.unikom.ac.id/?direktori/op endir/4/openkategori/1/openitem/3355/ John Naisbitt. (1994). Global paradox The Bigger the World Economy, the More Powerful its Smallest Players (p. 304). p. $304 . \quad$ Retrieved from https://archive.org/details/globalparado 
xbig00nais

Kalebos, F. (2016). Faktor-Faktor yang Mempengaruhi Kepuasan Wisatawan yang Berkunjung ke Daerah Wisata Kepulauan. Jurnal Riset Bisnis Dan Manajemen, 4(3), 489-502.

Kotler Philip. (2005). Manajemen

Pemasaran, Edisi Kesebelas. Jakarta:

Erlangga.

Lamb, H. dan M. (2002). Pemasaran, Buku 1, Edisi Pertama. Jakarta: Salemba Empat.

Mowen, J. C. dan M. M. (2002). Perilaku Konsumen, Jilid I, Edisi Kelima. Jakarta: Erlangga.

Peter. J, Paul \& Olson. Jerry, C. (1999). Perilaku Konsumen dan Strategi Pemasaran, Edisi 4, Jilid 2. Jakarta: Erlangga.

Salomon, Michael, R. (2002). Consumer Behavior, 5th Edition (5th ed.). New Jersey: Prentice Hall, Inc.

Shamdasani, P.N. \& Balakrishnan, A. A. (2000). Determinants of Relationship Quality and Loyalty in Personalized Services. Asia Pacific Journal of Management, 17(3), 399-422. Retrieved from http://scholarbank.nus.edu.sg/handle/1 0635/45142

Wahyu Adityo Prodjo. (2019, May 9). Indeks Daya Saing Pariwisata Indonesia Tahun 2019 Naik. Kompas.Com. Retrieved from https://travel.kompas.com 